\title{
Numerical modelling of historical landslide-generated tsunamis in the French Lesser Antilles
}

\author{
B. Poisson and R. Pedreros \\ BRGM - Land Use Planning and Natural Hazards, 3 avenue Claude Guillemin, BP 36009, 45060 Orléans Cedex 2, France
}

Received: 24 December 2009 - Revised: 6 April 2010 - Accepted: 18 May 2010 - Published: 17 June 2010

\begin{abstract}
Two historical landslide-induced tsunamis that reached the coasts of the French Lesser Antilles are studied. First, the Martinique coast was hit by a tsunami down the western flank of Montagne Pelée at the beginning of the big eruption of May 1902. More recently, the northeastern coast of Guadeloupe was affected by a tsunami that had been generated around Montserrat by pyroclastic flows entering the sea, during the July 2003 eruption of the Soufrière Hills volcano. We use a modified version of the GEOWAVE model to compute numerical simulations of both events. Two source hypotheses are considered for each tsunami. The comparison of the simulation results with reported tsunami height data helps to discriminate between the tested source decriptions. In the Martinique case, we obtain a better fit to data when considering three successive lahars entering the sea, as a simplified single source leads to an overstimation of the tsunami wave heights at the coast. In the Montserrat case, the best model uses a unique source which volume corresponds to published data concerning the peak volume flow. These findings emphasize the importance of an accurate description of the relevant volume as well as the timing sequence of the source event in landslide-generated tsunami modelling. They also show that considering far-field effects in addition to near-field effects may significantly improve tsunami modelling.
\end{abstract}

\section{Introduction}

Mass wasting events affecting volcanoes are known to be potentially tsunamigenic (Latter, 1981; Lockridge, 1990). Among them, volcano flank collapses and pyroclastic flows may generate tsunamis when volcanic material reaches the

Correspondence to: B. Poisson (b.poisson@brgm.fr) sea and flows underwater (Carey et al., 1996; Ward and Day, 2003; Watts and Waythomas, 2003). Such tsunamis may have far disastrous effects, when the involved volume of material entering the sea reaches cubic kilometers, as for the 1883 Krakatau eruption in Indonesia, $12 \mathrm{~km}^{3}$ (Mandeville et al., 1996), and for the 1888 Ritter volcano collapse in New Guinea, $5 \mathrm{~km}^{3}$ (Ward and Day, 2003). When much smaller volumes are concerned, landslide-generated tsunamis have generally localized effects (Tinti et al., 2005; Maeno et al., 2006). The tsunami waves do not propagate far away because of their small wavelengths and because of dispersion (Watts et al., 2003). The tsunami effects can be, however, very destructive on the surrounding shore (Tappin et al., 2001; Fritz et al., 2001).

The Lesser Antilles arc extends over $800 \mathrm{~km}$ from north to south between the Atlantic Ocean and the Caribbean Sea (Fig. 1). The volcanic island arc is originated by the subduction of Atlantic oceanic plate beneath the Caribbean plate. Most of the islands in the Antilles are a few kilometers to a few tens of kilometers long. Active volcanoes are typically 1000 to $1500 \mathrm{~m}$ high for 10 to $20 \mathrm{~km}$ diameters. Both the high relief and the volcanic activity contribute to landslide hazards. Several analysis of submarine deposits along the Lesser Antilles arc suggest that numerous large-scale debris avalanches have occurred during the past thousand years (Deplus et al., 2001; Le Friant et al., 2004, 2006).

Two volcanic events involving ocean-entering debris flows are known to have generated tsunamis on the coasts of the French Antilles. The first is the catastrophic eruption of the Montagne Pelée volcano in Martinique that lasted several months in 1902. Big volumes of pyroclastic material entered the sea at several times during successive phases of eruption. They likely generated several tsunamis, among which only one is described in historical documents (New York Times, 1902; Berté, 1902; Chrétien and Brousse, 1988; Scarth, 2002, Table 1). On 5 May, a lahar flowed from the volcano summit caldera and generated tsunami waves,

Published by Copernicus Publications on behalf of the European Geosciences Union. 


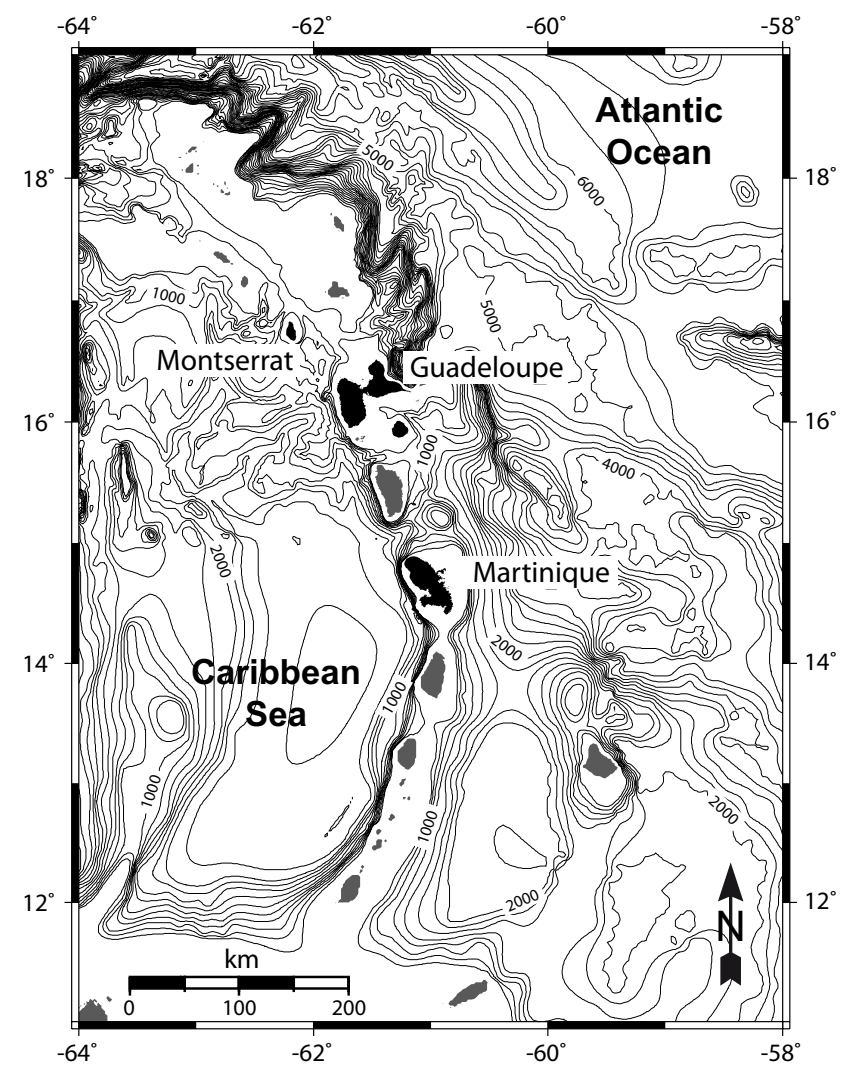

Fig. 1. Location map of studied area in the Lesser Antilles Arc. Bathymetric contours at 500 m-intervals are from GEBCO data.

mainly in the Saint-Pierre area. The tsunami claimed no victims but material damage was reported (Berté, 1902). The second identified event is the eruption of the Soufrière Hills volcano on Montserrat that began in 1995 and has continued at odd moments since. On 13 July 2003, a major dome collapse occurred and delivered large pyroclastic flows into the sea, thus leading to the generation of a tsunami (Pelinovsky et al., 2004; Edmonds and Herd, 2005). The tsunami mainly affected the eastern uninhabited shore of Montserrat, but it also reached Antigua northeastwards and the Guadeloupe southeastwards. There was no damage because it occurred during the night and because crest amplitudes of generated waves did not exceed $1 \mathrm{~m}$ (Pelinovsky et al., 2004, Table 2). Another significant dome collapse occurred on 20 May 2006, causing a small tsunami observed at Deshaies with a height of less than $1 \mathrm{~m}$ (Zahibo, 2006).

In this paper, we carry out numerical modelling of both these tsunami events. We use the GEOWAVE model to simulate the generation and propagation of tsunami waves (Watts et al., 2003). This model is extensively used in tsunami modelling, and has been applied to landslide-generated tsunamis (Waythomas and Watts, 2003; Mattioli et al., 2007). We then make the hypothesis that it can reproduce realistic tsunami waves and describe well the tsunami impact at the coast. In order to give a good description of the tsunami wavelength nearshore, a nesting system is implemented (Poisson et al., 2009). Numerical modelling of the Martinique 5 May 1902 tsunami event is carried out for the first time. For this event, the parameters are based on available data and we take into account two distinct ways of considering the same global volume. In the case of the Montserrat 2003 event, we attempt to simulate the tsunami impact on the Guadeloupe shoreline. We first try to use model parameters taken from a published modelling study of the same event (Mattioli et al., 2007). As these parameters give poor results on the Guadeloupe shore, we modify them with the help of other published data in order to better match the observations. In each case, the different parameters are discussed through the comparison between simulation results and historical observations.

\section{Numerical modelling}

\subsection{Tsunami generation and propagation}

In this study as in Mattioli et al. (2007), we use the tsunami generation, propagation and inundation model GEOWAVE (Watts et al., 2003). The initial tsunami (surface water deformation and velocity) is computed through the generation model TOPICS from the following landslide parameters: landslide entry location, width, strike and velocity; landslide volume reaching the sea; runout length and time in water (Walder et al., 2003; Watts et al., 2003; Watts and Waythomas, 2003; Mattioli et al., 2007, see Appendix A). TOPICS does not deal with the splash zone, which is an area of complicated wave dynamics (e.g., Fritz et al., 2004). It however computes the characteristics of the tsunami wave in the near-field zone, where a well-defined wave evolves from the splash zone (e.g., Walder et al., 2003). Then, propagation and inundation of tsunami waves are computed with FUNWAVE, a model based on fully nonlinear Boussinesq equations accounting for frequency dispersion (Wei et al., 1995, see Appendix B).

As mentioned by Van Boskirk et al. (2004) who also applied GEOWAVE to the Montserrat 2003 case, the most important parameters in the simulation of landslide-generated waves (in the near-field only, not in the splash zone) with GEOWAVE are the volume of material entering the sea and the runout length of underwater motion, which is correlated with the runout time and the final depth $h$. As the duration of underwater motion $t_{\mathrm{u}}$ is generally unknown, we deduce it from the estimation of impact velocity $v_{\mathrm{i}}$ and distance of underwater runout $r_{\mathrm{u}}$. We can refer to Waythomas et al. (2006)'s simplified model of a debris avalanche motion to support the intuitive relationship between these three parameters: as the debris flow velocity decreases almost linearly from the impact at the shoreline to the stopping point, $t_{\mathrm{u}}$ can be approximately estimated to half the ratio between $r_{\mathrm{u}}$ and $v_{\mathrm{i}}$. 
Then, the flow impact velocity does not directly influence the tsunami calculation. It is implicitly related to $t_{\mathrm{u}}$ and determines the landslide Froude number $F r=v_{\mathrm{i}} / \sqrt{g h}$, from which depends the efficiency of debris flow tsunami generation (Watts and Waythomas, 2003) and the wave dynamics in the splash zone (Fritz et al., 2004). In this study, we have $\mathrm{Fr}<3$, which is included in the domain of validity of TOPICS equations where the near-field wave characteristics are independent of $\mathrm{Fr}$ (Walder et al., 2003).

\subsection{Nesting system}

The aim is to compute tsunami waves with correct attributes. The most important task is to accurately describe the tsunami wavelength, which is related to the source characteristics. In case of a debris-flow generated tsunami, the wavelength is around a few kilometers and may even decrease when reaching the nearshore zone. The spatial resolution of the computational grid must be chosen according to this wavelength. If the relevant resolution is too small to use a common grid including both the source and the area of the affected coast, a system of nested grids is required. We have, therefore, implemented such a nesting system in GEOWAVE (Poisson et al., 2009). A first complete run is performed on a grid with $\delta x_{0}$-uniform spacing, during which water height and velocities are recorded at the limits of the second domain included within the first. Then, these conditions are interpolated at the boundaries of the second domain according to the chosen nested grid resolution $\delta x_{1}<\delta x_{0}$ and used to more accurately compute through a new run the tsunami propagation on this finer grid. If needed, the nesting process may be iterated, provided that each subgrid resolution is lower than the ascending. In our simulations, we chose to use a nested ratio of 3 , so that $\delta x_{1}=\delta x_{0} / 3$.

\subsection{Bathymetric data}

Bathymetric grids are derived from several datasets of various resolutions. SHOM (French Naval Hydrographic and Oceanographic Service) bathymetric measurements are available for the Guadeloupe and Martinique regions, with non-uniform density. The resolution of these data is of $2 \mathrm{~km}$ for depth greater than $1000 \mathrm{~m}$, around $250 \mathrm{~m}$ for the range $1000-100 \mathrm{~m}$, and from 20 to $40 \mathrm{~m}$ near the coast, for depths smaller than $100 \mathrm{~m}$. Where the SHOM coverage is deficient and for the Montserrat region, we use GEBCO worldwide dataset from NOAA, which has a resolution of $1^{\prime} \times 1^{\prime}$.

SRTM elevation data with $3^{\prime \prime} \times 3^{\prime \prime}$ resolution are used for topography. It is important to note that tsunami run-up and induced inondation are very sensitive to local shallow bathymetry and shore topography. In this study, available topobathymetric data do not have a fine enough resolution to allow the numerical modelling of such processes. SRTM data are not very accurate at the shore and we just use them

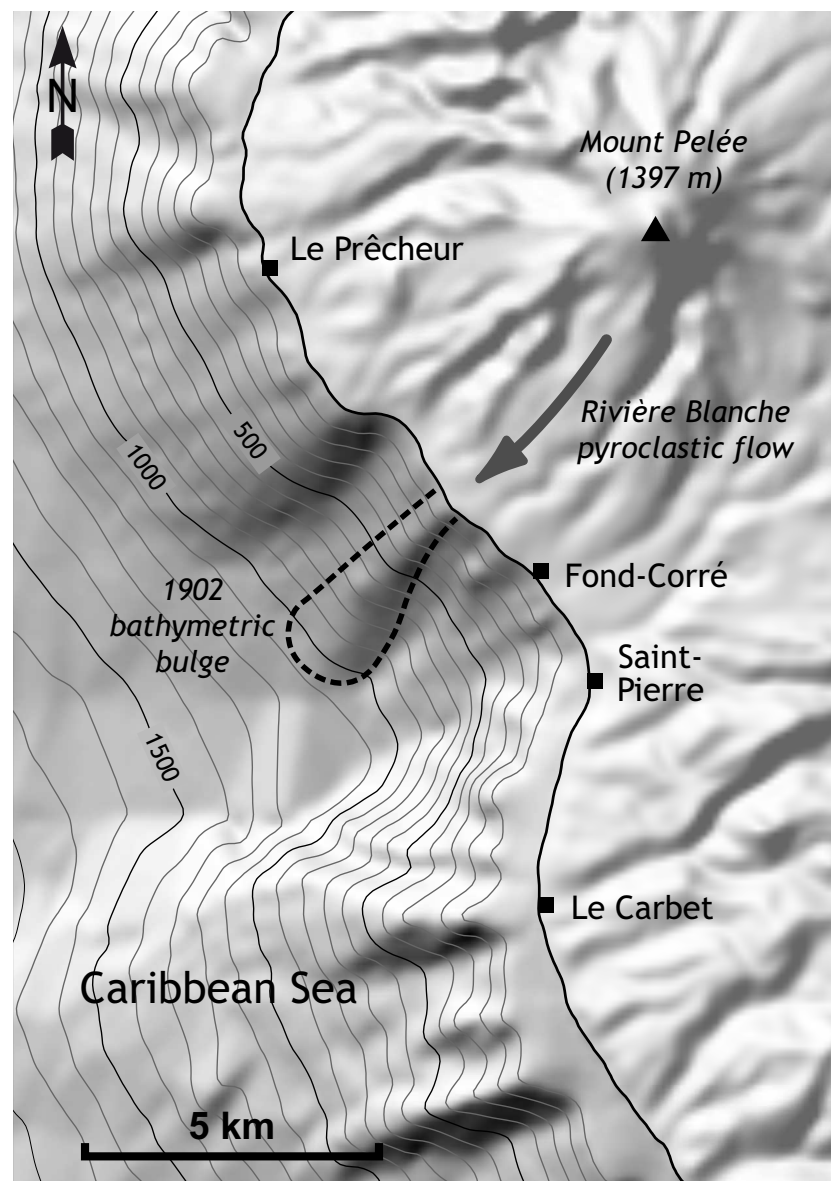

Fig. 2. Location map of the Martinique northwestern coast where a lahar entered the sea and generated a tsunami on 5 May 1902. 100$\mathrm{m}$ topobathymetric grid from SHOM and SRTM data is reported (contour interval is $100 \mathrm{~m}$ ).

to fill the emerged area, but the model results will only be discussed in their offshore part, where correct bathymetric data exist.

We use the Mercator projection to build rectangular uniform grids from topobathymetric data with spatial resolutions from $300 \mathrm{~m}$ to $33 \mathrm{~m}$, according to the expected tsunami wavelength.

\section{Martinique: lahar at Montagne Pelée, 5 May 1902}

\subsection{Setting}

Martinique is a French island located at around $14^{\circ} 40^{\prime} \mathrm{N}$, $61^{\circ} 00^{\prime} \mathrm{W}$ (Fig. 1). Its northern part consists of an active volcano, the Montagne Pelée. No magmatic eruption occurred between 1635 and 1902 (Bourdier et al., 1989). The most deadly eruption of the 20th century was the event of 8 May 1902, when the city of Saint-Pierre was destroyed by a nuée ardente killing almost 28000 people (Lacroix, 1904, Fig. 2). A few weeks of fumarolic activity and phreatic events 

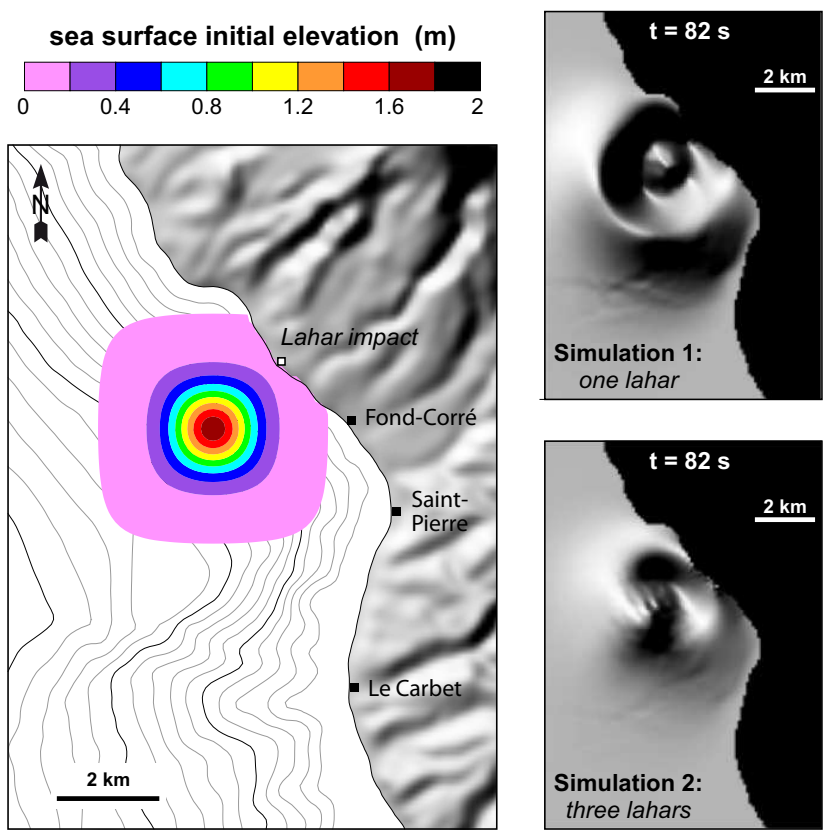

Fig. 3. Left: sea surface elevation at the generation of the simulated Martinique 1902 tsunami. In Simulation 2, it corresponds to the three cumulated sea surface deformations related to the three subsources. Right: snapshots of shaded sea surface at $t=82 \mathrm{~s}$, for both simulations.

preceded the main eruption of 8 May (Chrétien and Brousse, 1989; Bourdier et al., 1989). These first phreatic eruptions formed a lake in the caldera of Etang Sec, which was the uppermost crater of the volcano (Berté, 1902; Chrétien and Brousse, 1989). The rocky wall that was damming the lake weakened because of preliminary events and broke up on 5 May. A large volume of lake water swept debris along its track and produced a lahar. During its descent to the sea along the Rivière Blanche valley, the Guérin factory was destroyed and 20-30 workers were killed. The entering of the lahar into the sea generated a tsunami, which mainly had local effects. Because of the catastrophic eruptions that struck the area a few days later, observations reports of the tsunami are rare. A few historical observations are nevertheless available (Berté, 1902; Saffache et al., 2003). Several waves were reported at Saint-Pierre, where the sea retreated around $50 \mathrm{~m}$ off the coast. The rare eyewitness reports give an estimation of $2 \mathrm{~m}$ for the wave crest amplitude and 1.5 to $2 \mathrm{~m}$ for the trough amplitude at this location. The tsunami was also observed in the south at Le Carbet and Fort-de-France while the road was inundated and houses were damaged further north at the hamlet of Fond-Corré (Berté, 1902; Lacroix, 1904, Fig. 2).

During the following eruptions of 8 May, 20 May, and 30 August 1902, other tsunamis likely occurred due to the entering of nuées ardentes into the sea, but no quantitative observations are available (New York Times, 1902; Scarth, 2002).

\subsection{Modelling and results}

A $100 \mathrm{~m}$ uniform spacing grid is derived from the SHOM data around Martinique completed with the GEBCO worldwide dataset. In this case, because of the small volume of the tsunami source, the wavelength decreases to around $800 \mathrm{~m}$ at the coast and a higher resolution than $100 \mathrm{~m}$ is needed to correctly model the tsunami waves. Consequently, a nested $33.3 \mathrm{~m}$ resolution grid around Saint-Pierre is built from SHOM data for a second and final run.

\subsubsection{Choice of parameters}

The volume of water temporarily stored in the Etang Sec lake was estimated as 5 million $\mathrm{m}^{3}$ (Chrétien and Brousse, 1989). The volume of the lahar that flowed into the sea is directly deduced to be of the same order of magnitude. It would have travelled from the Etang Sec in three minutes, so that a velocity of around $40 \mathrm{~m} \mathrm{~s}^{-1}$ seems plausible (Chrétien and Brousse, 1989; Tanguy, 1994). Where the debris flow of 5 May 1902 entered the sea, the sea bottom now exhibits a bathymetric bulge from 0 to around $1000 \mathrm{~m}$ deep (Fig. 2). We propose setting the runout distance according to this morphology. The observed bulge at the mouth of Rivière Blanche is likely due to nuées ardentes submarine deposits of May and August 1902 eruptions. Its volume is estimated from bathymetric data to be around 50 million $\mathrm{m}^{3}$, which is 10 times bigger than the volume of the 5 May lahar. As it was emplaced first, the lahar deposit may have stopped far before the present deeper limit of the bulge. We then impose a $400 \mathrm{~m}$ final depth for the debris flow, and deduce a runout distance in water of $1000 \mathrm{~m}$ and a runout duration of $50 \mathrm{~s}$.

Some historical observations mentioned the occurrence of three successive flows of debris and mud (Chrétien and Brousse, 1989). We then test two sets of parameters: in the first (Simulation 1), a singular lahar of 5 million $\mathrm{m}^{3}$ enters the sea, whereas in the second (Simulation 2), three lahars of 1.7 million $\mathrm{m}^{3}$ flow sequentially into the sea during a 1 minute interval, that is one every $30 \mathrm{~s}$.

A control experiment is carried out, alongside, with bathymetric data without the bulge of 50 million $\mathrm{m}^{3}$, which should be closer to the pre-eruption bathymetry. It shows the same results as those with the unrectified bathymetry, confirming that the tsunami generation and propagation are not biased by the use of the present-day bathymetry.

\subsubsection{Results}

From Le Carbet to Fond-Corré, near the source, the tsunami wavelength is too short to be properly described through the first run on the 100-m topobathymetric grid. Only the results of the second run at 33-m resolution can therefore be considered. On the contrary, at Fort-de-France, the tsunami wavelength is of around $2-3 \mathrm{~km}$, a value which is much larger than in the Saint-Pierre area near the source. We can then consider that the results of the first run are correct. 
The initial cumulated deformation of the sea surface due to the three successive lahars in Simulation 2 equals the deformation due to the single lahar of Simulation 1 (Fig. 3). However, the different timing in Simulation 2 leads to a very different wave generation, as it can be observed less than $2 \mathrm{~min}$ after the first impact of the lahar into the sea (Fig. 3, right).

This initial effect might lead us to believe that the induced tsunami will be larger in Simulation 1 than in Simulation 2, but the details of the final outcome at the targeted sites disagree with this prediction. Although the map of maximum crest amplitude seems to show a smaller extent of high tsunami waves in Simulation 2, the maximum wave amplitudes at the targeted sites (points of historical observations) is indeed of the same order of magnitude in both simulations (Fig. 4, zoom).

As could be expected, the simulated tsunami effects are very localized on a $20-30-\mathrm{km}$ shore section, from a few kilometers north to the lahar entry to Fort-de-France (Fig. 4). Towards the open sea, the tsunami is quickly dissipated and does not reach any other island.

Whatever the case, the most affected site is Saint-Pierre. The coast further south is only hit in Simulation 1 (Fig. 4). On the contrary, in Simulation 2, the area between Le Carbet and Fort-de-France is only slightly affected. In the case of a single lahar, the first generated waves are important and are reflected by the harbour of Saint-Pierre; when the fourth generated wave is added to the reflected first one at Le Carbet, the resulting combined wave is twice as high as it would be without the gathering effect. In contrast, if three small lahars come in succession, the direct generated waves are not so important and the same gathering effect leads to a wave only half as high. However, the coastal amplification and interferences between direct and reflected waves come to a similar first wave in both cases. At Fort-de-France, the deceleration of wave propagation and the associated decrease in wavelength also leads to a gathering effect along the coastline. The resulting wave there is of the same shape, but with a different amplitude according to the simulation.

The computed crest and trough amplitudes of simulated tsunamis are reported in Table 1 at four sites where it was observed on 5 May 1902. The only quantified historical observation comes from the harbour of Saint-Pierre, where the first wave is estimated to have risen $2 \mathrm{~m}$ above its zero level, and then to have dropped around $2 \mathrm{~m}$ below (Berté, 1902). Both simulations are in agreement with this evaluation.

At Fond-Corré, near the source, the road is known to have been inundated. The simulated waves are not very high there, so that they could hardly have flowed so far, but this is likely due to a bias in topobathymetric data. Indeed, at Fond-Corré the $20 \mathrm{~m}$-depth seems to be reached at $70 \mathrm{~m}$ from the shoreline, while the 1:25000 topographic map of the IGN (French National Geographic Institute) indicates that it should be as far as $150 \mathrm{~m}$ from the shoreline. This misrepresentation naturally leads to an underestimation of wave amplitude. We then can assume that the simulations results at Fond-Corré
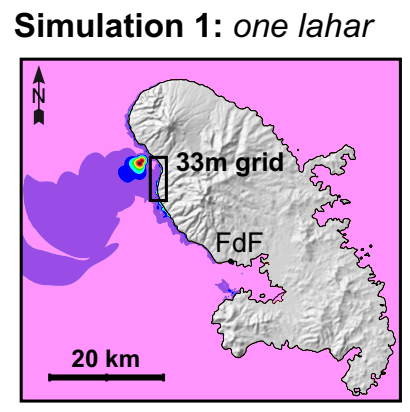

Simulation 2: three lahars
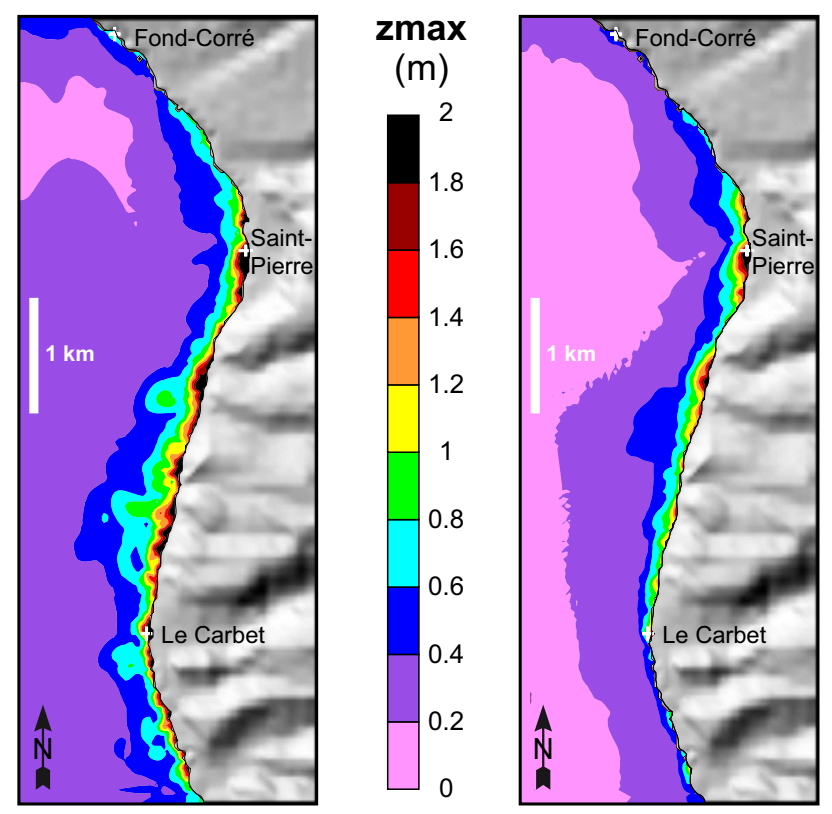

Fig. 4. Maximum sea surface elevation computed during the simulated Martinique 5 May 1902 tsunami generation and propagation, for both tested parameters sets. Upper and lower maps show results on the $300 \mathrm{~m}$ and $33 \mathrm{~m}$ grids, respectively. FdF: Fort-de-France.

are a lower bound for the 1902 actual tsunami, and this point is consistent with the observation of the inundated road.

According to the results of both simulations, a disturbance of sea surface may actually have been observed at Le Carbet. However, wave amplitudes in Simulation 1 are somewhat too high not to have been reported as remarkable. At this site, Simulation 2 gives a more plausible result, although the simulated main wave is also large with a crest-to-trough height of more than $2 \mathrm{~m}$.

Finally, both simulations show that Fort-de-France is reached by a tsunami wave, around 14 min after the lahar enters the sea. In both cases, the crest amplitude smaller than $0.5 \mathrm{~m}$ is consistent with the historical reports of ebb and flow in the bay. The observed sea retreat can be explained by the shallow water near the shore, as a $5 \mathrm{~m}$-depth is reached at $100 \mathrm{~m}$ only from the coast. Indeed, this configuration enhances the ratio between sea retreat and trough amplitude of the tsunami wave. 
Table 1. Historical observations of the Martinique 5 May 1902 tsunami and maximum crest and trough amplitudes (in meters) computed at observation locations (Berté, 1902; Saffache et al., 2003).

\begin{tabular}{llcl}
\hline Site & Observations & Simulation $1^{\mathrm{a}}$ & ${\text { Simulation } 2^{\mathrm{b}}}$ \\
\hline Fond-Corré & road inundated & $-0.6 /+0.8$ & $-0.7 /+0.6$ \\
Saint-Pierre & trough: $1.5-2 \mathrm{~m}$, crest: $+2 \mathrm{~m}$ & $-2.2 /+2.3$ & $-2.2 /+2.0$ \\
Le Carbet & oscillations & $-1.9 /+1.8$ & $-1.4 /+1.2$ \\
Fort-de-France & oscillations, large retreat, amplitude $\sim 0.1 \mathrm{~m}$ & $-0.5 /+0.4$ & $-0.3 /+0.3$ \\
\hline
\end{tabular}

${ }^{a}$ One single lahar. ${ }^{b}$ Three successive lahars.

Arrival times of tsunami waves are not exactly known, because of historical data sparsity and uncertainty. Nevertheless, the lahar is assumed to have destroyed the Guérin factory around 1:30 p.m., as the first oscillation at Fort-deFrance was observed at 1:40 p.m. (Berté, 1902; Chrétien and Brousse, 1988). Our simulation results fit well with this timing. Historical reports of the duration of oscillations are quite inconsistent and do not help to appraise the modelling results. The tsunami effects could have lasted around a quarter of an hour and fifteen oscillations could have occurred, but other observations assert that it lasted a much shorter time (Chrétien and Brousse, 1988). One eyewitness reported that after the first retreat in Saint-Pierre, the sea returned "one or two minutes" later (Chrétien and Brousse, 1988). Both simulations are in agreement with this observation, thus validating the simulated tsunami period. This is an important point in validating our choice of the source parameters.

\section{Montserrat: dome collapse at Soufrière Hills, 13 July 2003}

\subsection{Setting}

Montserrat is a British island located at around $16^{\circ} 39^{\prime} \mathrm{N}$, $62^{\circ} 12^{\prime} \mathrm{W}$ (Fig. 1). It is composed of three volcanic massifs, among which the younger Soufrière Hills lies to the south. With no recorded historical eruption, the volcano was considered as dormant until 1995 (Shepherd et al., 1971), when an eruption began which is still continuing today. This eruption is characterized by a sequence of alternating phases of dome growth and collapse events (Trofimovs et al., 2006). The released pyroclastic flows (PFs) along the volcano flanks frequently reached the shore. According to Trofimovs et al. (2006), over $90 \%$ of the material produced until 2006 had been deposited into the ocean. Among all collapse events, just a few are known to have generated tsunamis. In December 1997, a debris avalanche with an estimated volume of 64 million $\mathrm{m}^{3}$ slid down the White River valley in the south and was followed by a PF of around 20 million $\mathrm{m}^{3}$ that reached the sea (MVO, 1998). It then generated a very localized 3-m high tsunami at Old Road Bay, $10 \mathrm{~km}$ further north on the western coast (MVO, 1998; Heinrich et al., 1998).
A few years later, on 12 and 13 July 2003, the largest and most intense lava dome collapse of the eruption occurred (Edmonds and Herd, 2005). During $18 \mathrm{~h}$, around 210 million $\mathrm{m}^{3}$ of dome material collapsed and travelled down the Tar River valley (Edmonds and Herd, 2005; Herd et al., 2005). The PFs reached the sea and apart from a few million $\mathrm{m}^{3}$, almost all the collapsed material entered the sea (Edmonds et al., 2006). At the shore, interactions between the PFs and the seawater caused intense hydrovolcanic activity, leading to a violent inland-directed pyroclastic surge (Edmonds and Herd, 2005). A tsunami was also generated. It had a strong impact on the Montserrat shoreline, as it eroded the fresh surge deposit up to $15 \mathrm{~m}$ above sea level (m a.s.l.). It also build a strandline with flotsam at $8.5 \mathrm{~m}$ a.s.l. on the Tar River fan (Herd et al., 2005; Mattioli et al., 2007). The tsunami simultaneously propagated towards Antigua and Guadeloupe and caused some damage to fishing boats in a few harbours (Pelinovsky et al., 2004; Edmonds and Herd, 2005).

Mattioli et al. (2007) suggested that multiple local tsunamis had been recorded in dilatometer measurements during several hours. When the eruption began, PFs were intermittent, and they became gradually continuous, until 13 July at 3:35 a.m., when the peak of intensity occurred. At that time, a large PF entered the sea and caused a tsunami offshore and a pyroclastic surge at the coast (Edmonds and Herd, 2005). The total volume of collapsed material was estimated as around 200 million $\mathrm{m}^{3}$, but the tsunami was probably generated by a volume flux of material of around 16 million $\mathrm{m}^{3}$ over two minutes (Herd et al., 2005).

\subsection{Modelling and results}

From GEBCO and SHOM combined data, we constructed two bathymetric grids with $300 \mathrm{~m}$ and $100 \mathrm{~m}$ uniform spacing: the first comprises Montserrat, Antigua and the whole Guadeloupe archipelago; the second is a nested grid centered on Basse Terre, the western part of the Guadeloupe main island.

A first run on the $300 \mathrm{~m}$ resolution grid computes rough tsunami heights at Montserrat as well as the limit conditions for the nested $100 \mathrm{~m}$ resolution grid. The second run computes the tsunami impact on the coast of interest. As the 

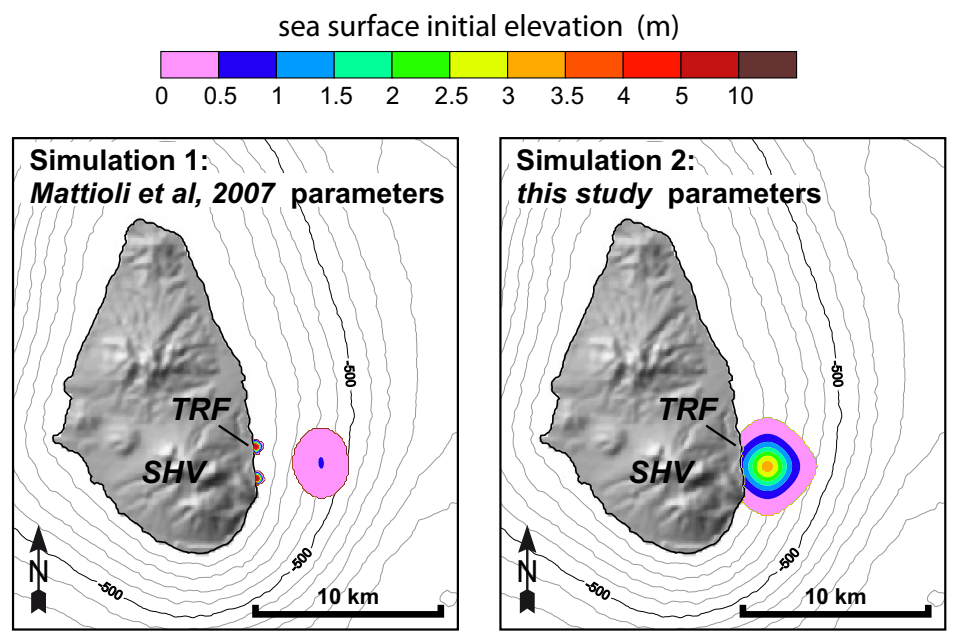

Fig. 5. Sea surface elevation at the generation of the simulated Montserrat 2003 tsunami, with original parameters from Mattioli et al. (2007) and with our modified parameters. SHV: Soufrière Hills Volcano, TRF: Tar river fan.

tsunami wavelength is of around $3 \mathrm{~km}$, it is well described on the $100 \mathrm{~m}$ resolution grid and a higher resolution is not needed.

\subsubsection{Choice of parameters}

In order to account for observations made at Montserrat around the Tar River fan, Van Boskirk et al. (2004) conducted numerical simulations with parameters that were detailed in Mattioli et al. (2007, suppl.). They used the Watts and Grilli (2003) model to compute the runout parameters for the debris flow tsunami source. From this computation, Mattioli et al. (2007) first deduced a runout distance of more than $5 \mathrm{~km}$, and then chose to divide the 7 million $\mathrm{m}^{3}$ source into five subsources along the PF entry arc with distinct values for flow direction azimuth, runout length and deduced runout time and final depth. Among them, the two first sources near the coast had a runout distance of $400 \mathrm{~m}$. The PF entry velocity into the sea was estimated to be $70 \mathrm{~m} \mathrm{~s}^{-1}$. We first try to use the same parameters (Simulation 1). However, as we extend the calculation domain to the western part of Guadeloupe, we find out that the tsunami propagating offshore is only a few centimeter-high and does not have a notable impact on the French coast. These inconsistent results led us to run another simulation with revised PF parameters for GEOWAVE (Simulation 2).

Our approach is then to consider a plausible first runout distance for the PF, not too far offshore. We may consider that the pyroclastic material could have moved again later and dispersed further, but not so fast as the first movement, which actually generated the wave. We deduce the significant runout distance and final depth from bathymetric observations reported by Hart et al. (2004). These authors reconstructed a map of the submarine pyroclastic deposits off of the Tar River valley by comparing a pre-eruption bathymetry to data acquired in July 1998 . They showed that the primary area of deposition nearest to the coast extended almost $1000 \mathrm{~m}$ from the Tar River fan. This area is a zone with gentler slopes, due to the spreading of the recent deposits. Due to a lack of more precise data on the runout distance, we then consider that the PF also stopped around $1000 \mathrm{~m}$ offshore, at a depth of $120 \mathrm{~m}$.

Then, we use the estimation of peak volume flux made by Herd et al. (2005) to set a 16 million $\mathrm{m}^{3}$ volume of pyroclastic material entering the sea. The impact velocity of such a PF is estimated to be of the order of $100 \mathrm{~m} \mathrm{~s}^{-1}$ (Herd et al., 2005). It is faster than flow velocity estimation for other Montserrat events, but the involved discharge is also larger (Cole et al., 1998). As the flow must have to decelerate during its runout in water, we choose a runout duration of $2 \mathrm{~min}$, which is also the duration of peak flow.

\subsubsection{Results}

The initial wave heights, computed with the parameters from Mattioli et al. (2007) (Simulation 1) and with our modified parameters (Simulation 2), are represented on Fig. 5. As a consequence of the difference in runout distance, the initial tsunami is very close to the coast in Simulation 1, whereas it forms a little further offshore in Simulation 2. The initial wave depends strongly on both the volume of PF and its final depth. Although the volume is more important in Simulation 2, the initial wave is much higher in Simulation 1 because the two main subsources have much smaller final depths ( $94 \mathrm{~m}$ and $38 \mathrm{~m}$ ). Indeed, we tested two simulations with the parameters from Mattioli et al. (2007): one with the five subsources, and another with only the first two near the coast. The maximum difference of computed wave elevation in the impact zone amounts to less than $10 \%$, revealing that the tsunami is mainly generated by the two 

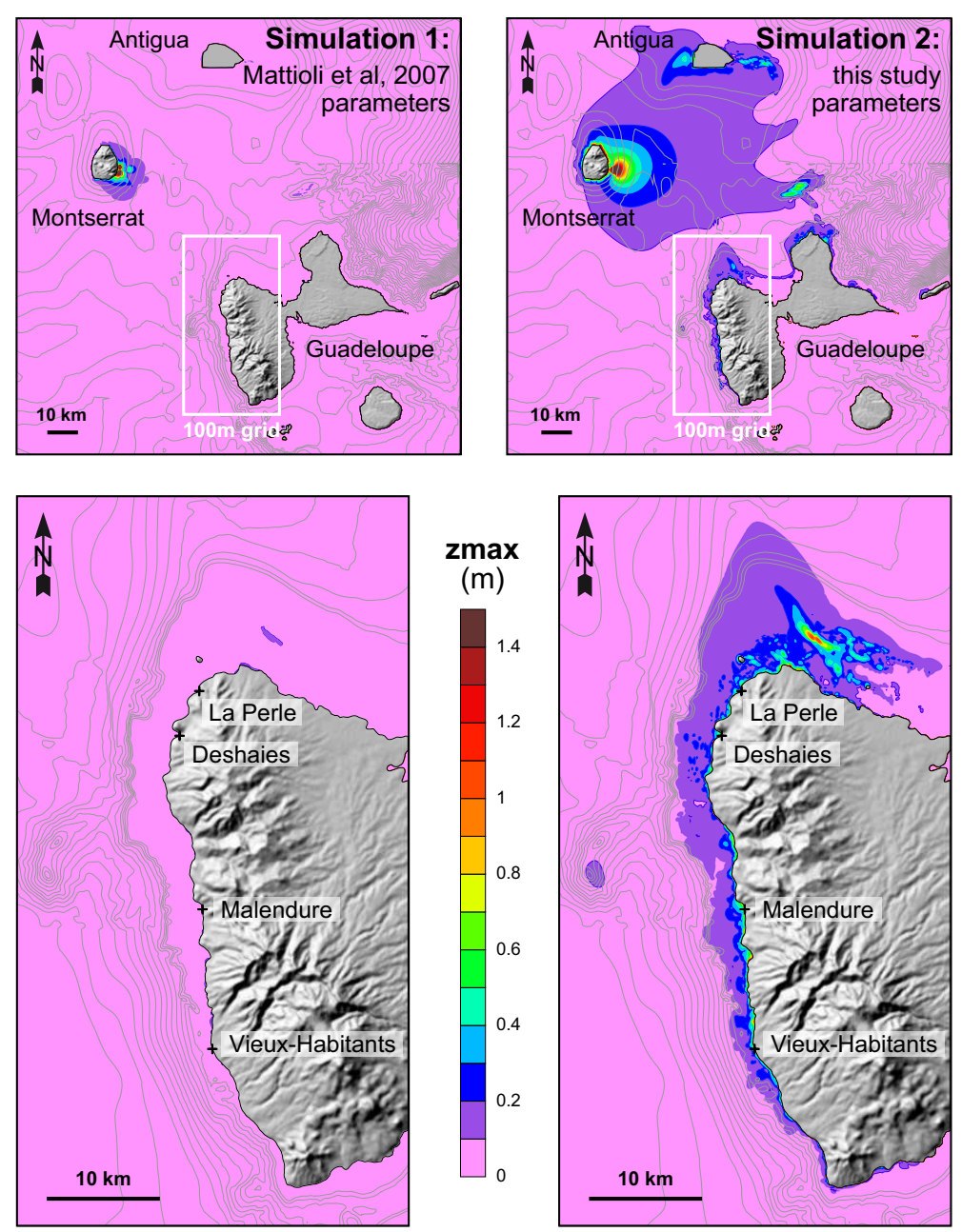

Fig. 6. Maximum sea surface elevation computed during the simulated Montserrat 2003 tsunami generation and propagation, for both tested parameters sets. Upper and lower maps show results on the $300 \mathrm{~m}$ and $100 \mathrm{~m}$ grids, respectively.

sources stopping near the coast. Although our bathymetric data around Montserrat have a lower resolution, we can deduce from this comparison that the only significant tsunami sources in this case are the PFs stopping nearest to the coastline.

Another significant difference between both simulations is that in Simulation 1, the spreading out of the PF in opposite directions leads to two $10 \mathrm{~m}$-high initial waves interacting afterwards whereas the Simulation 2 consists of a single wave.

The field data show that on the eastern coast of the island, the surge deposits had been partly eroded and washed away by the tsunami, thus indicating that the tsunami came after the surge (Herd et al., 2005). In the numerical modelling, the time shift between the PF entering the sea and the moment when the tsunami reached the coast is shorter in Simulation 1 than in 2. The conditions of Simulation 2 are therefore more consistent with the observations, even though the hypothesis of several later waves could also explain them (Mattioli et al., 2007).
We do not have available accurate enough bathymetric data around Montserrat to actually compare wave height results at the coast. Nevertheless, for calculations on an oversampled $100 \mathrm{~m}$ resolution grid around Montserrat island, we observe that in Simulation 1, the tsunami height exceeds $3 \mathrm{~m}$ at only a few points whereas in Simulation 2, it reaches 3.5$4 \mathrm{~m}$ in several places further north. This is not yet as high as the tsunami deposits reported in Mattioli et al. (2007), but it almost fits the tsunami scars observed by Herd et al. (2005).

Far from Montserrat, maximum sea surface elevation maps show a clear disagreement between the two simulations (Fig. 6). In Simulation 1, Antigua and Guadeloupe are almost not affected, whereas significant waves reach both islands in Simulation 2. When the tsunami reaches the Guadeloupe coast, the differences between the simulations results can be quantified. Four numerical gauges are located at the places where observations are reported (Pelinovsky et al., 2004, Table 2). In Simulation 1, the computed maximal wave height does not exceed $0.15 \mathrm{~m}$ where observations are on the order 
Table 2. Maximum wave crest amplitude (in meters) of the Montserrat 2003 tsunami, computed and measured at observation locations (Pelinovsky et al., 2004).

\begin{tabular}{llll}
\hline Site & Observations & ${\text { Simulation } 1^{\mathrm{a}}}$ & Simulation 2 $^{\mathrm{b}}$ \\
\hline (a) Plage de la Perle & 0.5 & 0.09 & 0.60 \\
(b) Deshaies & $0.5-1$ & 0.15 & 0.85 \\
(c) Malendure & 0.46 & 0.12 & 0.79 \\
(d) Vieux Habitants & 0.6 & 0.09 & 0.66 \\
\hline
\end{tabular}

${ }^{a}$ Mattioli et al. (2007) parameters.

b Our parameters.

of $0.5 \mathrm{~m}$. The ratio between the observed and computed wave height at all sites ranges from 4 to 7 . By contrast, Simulation 2 computed wave heights are of the same order of magnitude as reported data at three sites. Malendure is the only place where the wave height is overestimated, but only by a factor less than 2 . Therefore, the comparison with observations clearly shows that the results of Simulation 2 are globally much more consistent with the data than Simulation 1 results at the Guadeloupe shoreline.

\section{Conclusions}

In this study, we simulate two historical landslide-generated tsunamis in the French Antilles. A modified version of the GEOWAVE model is used, which can take properly into account the decreasing tsunami wavelength nearshore through a system of nested grids.

In the case of the Martinique 5 May 1902 event, two simulations are performed that differ by the kinematic representation of the debris flow entering into the sea. In Simulation 1, the whole volume of fallen debris is considered as a single lahar of 5 million $\mathrm{m}^{3}$, whereas it is subdivided in three distinct flows in Simulation 2, thus entering the sea during $1 \mathrm{~min}$ and not instantaneously. Both simulated tsunamis agree with reported wave amplitudes at Saint-Pierre, $3.5 \mathrm{~km}$ far from the lahar impact. Further south, Simulation 2 results are in better agreement with the historical observations, which tell of a sea surface disturbance, but presumably nothing large.

During the Montserrat event of July 2003, 98\% of the 200 millions $\mathrm{m}^{3}$ of collapsed material reached the sea (Edmonds et al., 2006). However, even if several tsunamis may have been locally generated, only the peak volume flow event generated a tsunami strong enough to reach the neighbouring Guadeloupe island (Mattioli et al., 2007). Both the Mattioli et al. (2007) simulation and ours show that a limited source volume can indeed generate a tsunami as was observed in Montserrat and in Guadeloupe. Potential volcano flank collapse, especially when considering large volumes of debris, are sometimes associated with tsunami hazards (Le Friant et al., 2003, 2006). In fact, the global volume of a potential huge landslide must not be identified as a direct tsunami source, as it would collapse and enter the sea during a noninstantaneous time sequence. Only the potential peak debris flow should be considered for the tsunami hazard assessment. Thus, the Montserrat tsunami event illustrates the fact that for a correct modelling of such a tsunami, a preliminary study must provide detailed characteristics of the debris flow event actually linked to the tsunami. When modelling the 2003 Montserrat event, a first simulation based on Mattioli et al. (2007) parameters of the main pyroclastic flow indicates that these parameters cannot explain the far-field tsunami effects on Guadeloupe. This discrepancy emphasizes the importance of taking into account as much data as possible, especially from various locations, in order to get a global assessment of the tsunami effects before the modelling. By modifying the pyroclastic flow description according to published bathymetric and volumetric data (Hart et al., 2004; Herd et al., 2005), we achieve a simulation of the tsunami wave amplitudes better matching observations along the Guadeloupe coast.

The combined results of both studied tsunamis lead to a similar conclusion about the importance of the timing sequence of the source event. In case of the Montagne Pelée 5 May 1902 event, considering three close successive lahars appears to lead to more realistic tsunami waves than taking into account one single large lahar. In the same way, the entering of debris flows into the sea during the 12-13 July 2003 Montserrat eruption had only generated a tsunami at the moment of peak volume flow. In both cases, the outcome shows that the temporal progression of a tsunamigenic landslide or debris flows has an essential influence on the generated tsunami waves. Moreover, both cases agree on the importance of taking into account effects on coasts as far as possible from the source to better constrain the tsunami source. 


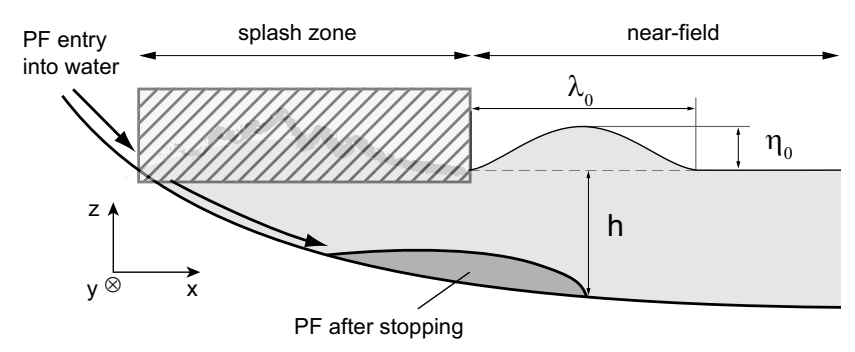

Fig. A1. Schematic diagram of the initial tsunami wave generated by the entry into water of a PF (based on Walder et al., 2003).

\section{Appendix A}

\section{TOPICS model for debris-flow induced tsunami generation}

According to Walder et al. (2003) analysis of several sets of experimental results, a solid or deformable block sliding down a flume into a body of water will generate a single, coherent wave profile with the approximate functional form (Fig. A1):

$$
\eta(x)=\eta_{0} \operatorname{sech}^{2}\left(\frac{x}{\lambda_{0}}\right)
$$

where $\eta$ is the sea surface elevation relative to the mean sea surface and $x$ the direction of propagation of the tsunami. The same factor of form $\operatorname{sech}^{2}\left(y /\left(\lambda_{0}+w\right)\right)$ determines the shape of the initial wave in the transverse direction $y$. The amplitude $\eta_{0}$ and the wavelength $\lambda_{0}$ are given by the following formulas:

$$
\begin{aligned}
& \eta_{0}=1.32 h\left(w t_{\mathrm{u}} \sqrt{g h^{3}} / V\right)^{-0.68} \\
& \lambda_{0}=0.27 t_{\mathrm{u}} \sqrt{g h}
\end{aligned}
$$

where $w$ is the debris flow width, $t_{\mathrm{u}}$ the duration of the motion underwater, $g$ the acceleration of gravity, $h$ the water depth near the end of debris flow motion, and $V$ the debris flow volume. Watts et al. (2003) show that the center of mass motion was of first order in the tsunami generation, while the material internal deformation was of second order, so that the description of the debris flow material is not needed in the computation.

\section{Appendix B}

\section{Elements about the FUNWAVE propagation model}

The model FUNWAVE is based on the fully nonlinear Boussinesq equations derived by Wei et al. (1995), and incorporates frictional damping, wave breaking and shoreline runup effects (Chen et al., 2000; Kennedy et al., 2000). The volume conservation is described by the equation:

$\beta \eta_{t}+\nabla_{\mathrm{h}} \cdot M=0$

where $\eta(x, y, t)$ is the surface displacement away from local mean depth $h(x, y), \nabla_{\mathrm{h}}$ is the horizontal gradient, and $M$ is the depth-integrated horizontal volume flux, given by:

$$
\begin{aligned}
M=\Lambda\left[u_{\alpha}+\right. & \left(\frac{z_{\alpha}^{2}}{2}-\frac{1}{6}\left(h^{2}-h \eta+\eta^{2}\right)\right) \nabla_{h} A \\
& \left.+\left(z_{\alpha}+\frac{1}{2}(h-\eta)\right) \nabla_{h} B\right]
\end{aligned}
$$

$u_{\alpha}$ is the horizontal velocity at the elevation $z_{\alpha}=-0.531 \mathrm{~h}$ defined with $z$ oriented upwards from the free surface (Wei et al., 1995). $A$ and $B$ are functions of velocity:

$A=\nabla_{\mathrm{h}} \cdot u_{\alpha}$

$B=\nabla_{\mathrm{h}} \cdot\left(h u_{\alpha}\right)$

The factors $\beta$ and $\Lambda$ were introduced by Kennedy et al. (2000) and Chen et al. (2000) to implement a porous beach method, in order to keep the subaerial domain computationally active and to simplify the calculation of runup on dry shorelines. They are given by:

$\beta= \begin{cases}1, & \text { if } \eta \geq z^{*} \\ \delta+(1-\delta) \mathrm{e}^{\lambda\left(\eta-z^{*}\right) / h_{0}}, & \text { if } \eta<z^{*}\end{cases}$
$\Lambda=\left\{\begin{array}{cc}\left(\eta-z^{*}\right)+\delta\left(z^{*}+h_{0}\right)+\frac{(1-\delta) h_{0}}{\lambda} & \text { if } \eta \geq z^{*} \\ \cdot\left(1-\mathrm{e}^{-\lambda\left(1+z^{*} / h_{0}\right)}\right), & \text { if } \eta<z^{*} \\ \delta\left(\eta+h_{0}\right)+\frac{(1-\delta) h_{0}}{\lambda} & \cdot \mathrm{e}^{\lambda\left(\eta-z^{*}\right) / h_{0}}\left(1-\mathrm{e}^{-\lambda\left(1+\eta / h_{0}\right)}\right),\end{array}\right.$

$h_{0}$ is the porous layer depth and must be higher than the depth of maximum wave rundown during a calculation. The choice of $z^{*}$ is discussed by Kennedy et al. (2000). Values of $\delta=0.08$ and $\lambda=25$ are chosen, following former studies of tsunami runup events (e.g., Watts et al., 2003). The momentum equations are:

$u_{\alpha t}+\left(u_{\alpha} \cdot \nabla_{h}\right) u_{\alpha}+g \nabla_{\mathrm{h}} \eta+V_{1}+V_{2}+R_{\mathrm{f}}-R_{\mathrm{b}}=0$

where $V_{1}$ and $V_{2}$ account for dispersive effects:

$$
\begin{aligned}
V_{1}= & \frac{z_{\alpha}^{2}}{2} \nabla_{\mathrm{h}} A_{t}+z_{\alpha} \nabla_{\mathrm{h}} B_{t}-\nabla_{\mathrm{h}}\left[\frac{\eta^{2}}{2} A_{t}+B_{t}\right] \\
V_{2}= & \nabla_{\mathrm{h}}\left[\left(z_{\alpha}-\eta\right)\left(u_{\alpha} \cdot \nabla_{\mathrm{h}}\right) B+\frac{1}{2}\left(z_{\alpha}^{2}-\eta^{2}\right)\left(u_{\alpha} \cdot \nabla_{\mathrm{h}}\right) A\right] \\
& +\frac{1}{2} \nabla_{h}\left[(B+\eta A)^{2}\right]
\end{aligned}
$$

and $R_{\mathrm{b}}$ and $R_{\mathrm{f}}$ are forces arising from wave breaking and bottom friction, respectively, and are formulated by Kennedy et al. (2000). FUNWAVE as used here does not include a 
moving bottom, and the initial tsunami is introduced as static surface elevation displacements. The described equations are implemented through a forward high-order finite difference scheme (composite 4th-order Adams Bashforth Moulton scheme; Kirby et al., 1998).

Acknowledgements. The SHOM (French Naval Hydrographic and Oceanographic Service) provided bathymetric data from the French Antilles. This work was partly funded by MEEDDAT (French Ministry for Ecology, Sustainable Development and Spatial Planning) through the Plan Séisme project. The authors are very grateful to John Douglas for improving the English of the manuscript.

Edited by: S. Tinti

Reviewed by: two anonymous referees

\section{References}

Berté, E.: Les éruptions de la Montagne Pelée - Récit et observations d'un témoin, La Géographie, VI, 133-141, 1902 (in French).

Bourdier, J. L., Boudon, G., and Gourgaud, A.: Stratigraphy of the 1902 and 1929 nuée-ardente deposits, Mt. Pelée, Martinique, J. Volcanol. Geoth. Res., 38, 77-96, 1989.

Carey, S., Sigurdsson, H., Mandeville, C., and Bronto, S.: Pyroclastic flows and surges over water: an example from the 1883 Krakatau eruption, B. Volcanol., 57, 493-511, 1996.

Chen, Q., Kirby, J. T., Dalrymple, R. A., Kennedy, A. B., and Chawla, A.: Boussinesq modeling of wave transformation, breaking, and inundation. II, J. Waterw. Port C. Div.-ASCE, 126, 48-56, 2000.

Chrétien, S. and Brousse, R.: La Montagne Pelée se réveille, Comment se prépare une éruption cataclysmique, Paris, 1988 (in French).

Chrétien, S. and Brousse, R.: Events preceding the great eruption of 8 May, 1902 at Mount Pelee, Martinique; Mount Pelee, J. Volcanol. Geoth. Res., 38, 67-75, 1989.

Cole, P. D., Calder, E. S., Druitt, T. H., Hoblitt, R., Robertson, R., Sparks, R. S. J., and Young, S. R.: Pyroclastic Flows Generated by Gravitational Instability of the 1996-97 Lava Dome of Soufriere Hills Volcano, Montserrat, Geophys. Res. Lett., 25, 3425-3428, 1998.

Deplus, C., Le Friant, A., Boudon, G., Komorowski, J. C., Villemant, B., Harford, C., Ségoufin, J., and Cheminée, J. L.: Submarine evidence for large-scale debris avalanches in the Lesser Antilles Arc, Earth Planet. Sc. Lett., 192, 145-157, 2001.

Edmonds, M. and Herd, R. A.: Inland-directed base surge generated by the explosive interaction of pyroclastic flows and seawater at Soufrière Hills volcano, Montserrat, Geology, 33, 245-248, 2005.

Edmonds, M., Herd, R. A., and Strutt, M. H.: Tephra deposits associated with a large lava dome collapse, Soufriere Hills Volcano, Montserrat, 12-15 July 2003, J. Volcanol. Geoth. Res., 153, 313330, 2006.

Fritz, H. M., Hager, W. H., and Minor, H. E.: Lituya Bay case: Rockslide impact and wave run-up, Science of Tsunami Hazards, 19, 3-22, 2001
Fritz, H. M., Hager, W. H., and Minor, H. E.: Near field characteristics of landslide generated impulse waves, J. Waterw. Port C. Div.-ASCE, 130, 287-302, 2004.

Hart, K., Carey, S., Sigurdsson, H., Sparks, R. S. J., and Robertson, R. E. A.: Discharge of pyroclastic flows into the sea during the 1996-1998 eruptions of the Soufrière Hills volcano, Montserrat, B. Volcanol., 66, 599-614, 2004.

Heinrich, P., Mangeney, A., Guibourg, S., Roche, R., Boudon, G., and Cheminee, J.-L.: Simulation of water waves generated by a potential debris avalanche in Montserrat, Lesser Antilles; The Soufriere Hills eruption, Montserrat, British West Indies; introduction to special section; Part 2, Geophys. Res. Lett., 25(19), 3697-3700, doi:10.1029/98GL01407, 1998.

Herd, R. A., Edmonds, M., and Bass, V. A.: Catastrophic lava dome failure at Soufriere Hills Volcano, Montserrat, 12-13 July 2003 , J. Volcanol. Geoth. Res., 148, 234-252, 2005.

Kennedy, A. B., Chen, Q., Kirby, J. T., and Dalrymple, R. A.: Boussinesq modeling of wave transformation, breaking, and inundation. I, J. Waterw. Port C. Div.-ASCE, 126, 39-47, 2000.

Kirby, J. T., Wei, G., Chen, Q., Kennedy, A. B., and Dalrymple, R. A.: FUNWAVE 1.0. Fully nonlinear Boussinesq wave model, Documentation and user's manual, Tech. Rep. CACR98-06, Center for Applied Coastal Research, Department of Civil and Environment Engineering, University of Delaware, 1998.

Lacroix, A.: La Montagne Pelée et ses éruptions, Paris, 1904 (in French).

Latter, J. H.: Tsunamis of volcanic origin: Summary of causes, with particular reference to Krakatoa, 1883, B. Volcanol., 44, 467-490, 1981.

Le Friant, A., Boudon, G., Deplus, C., and Villemant, B.: Largescale flank collapse events during the activity of Montagne Pelée, Martinique, Lesser Antilles, J. Geophys. Res.,, 108, 2055, doi:10.1029/2001JB001624, 2003.

Le Friant, A., Harford, C. L., Deplus, C., Boudon, G., Sparks, R. S. J., Herd, R. A., and Komorowski, J. C.: Geomorphological evolution of Montserrat (West Indies): importance of flank collapse and erosional processes, J. Geol. Soc., 161, 147-160, 2004

Le Friant, A., Boudon, G., Komorowski, J.-C., Heinrich, P., and Semet, M. P.: Potential flank-collapse of Soufriere Volcano, Guadeloupe, Lesser Antilles? Numerical simulation and hazards, Nat. Hazards, 39, 381-393, 2006.

Lockridge, P. A.: Nonseismic phenomena in the generation and augmentation of tsunamis, Nat. Hazards, 3, 403-412, 1990.

Maeno, F., Imamura, F., and Taniguchi, H.: Numerical simulation of tsunamis generated by caldera collapse during the $7.3 \mathrm{ka}$ Kikai eruption, Kyushu, Japan, Earth Planets Space, 58, 1013-1024, 2006.

Mandeville, C. W., Carey, S., and Sigurdsson, H.: Magma mixing, fractional crystallization and volatile degassing during the 1883 eruption of Krakatau volcano, Indonesia, J. Volcanol. Geoth. Res., 74, 243-274, 1996.

Mattioli, G. S., Voight, B., Linde, A. T., Sacks, I. S., Watts, P., Widiwijayanti, C., Young, S. R., Hidayat, D., Elsworth, D., Malin, P. E., Shalev, E., Van Boskirk, E., Johnston, W., Sparks, R. S. J., Neuberg, J., Bass, V., Dunkley, P., Herd, R., Syers, T., Williams, P., and Williams, D.: Unique and remarkable dilatometer measurements of pyroclastic flow-generated tsunamis, Geology, 35, 25-28, 2007. 
MVO: Special report 6 - The Boxing Day Collapse, Tech. rep., Montserrat Volcano Observatory, 1998.

New York Times: Hundred Dead in Martinique - A tidal wave at Le Carbet, 1902, September 2, p. 1, 1902.

Pelinovsky, E., Zahibo, N., Dunkley, P., Edmonds, M., Herd, R., Talipova, T., Kozelkov, A., and Nikolkina, I.: Tsunami generated by the volcano eruption on July 12-13, 2003 at Montserrat, Lesser Antilles, Science of Tsunami Hazards, 22, 44-57, 2004.

Poisson, B., Garcin, M., and Pedreros, R.: The December 26, 2004 Indian Ocean tsunami impact on Sri Lanka: cascade modelling from ocean to city scales, Geophys. J. Int., 177, 1080-1090, 2009.

Saffache, P., Marc, J. V., Mavoungo, J., Huygues-Belrose, V., and Cospar, O.: Tremblements de terre et raz de marée dans les Départements Français d'Amérique (1643-2002) : éléments pour un aménagement raisonné et un prise de conscience de la vulnérabilité du milieu, Paris, 2003 (in French).

Scarth, A.: La Catastrophe - The Eruption of Mount Pelee, the Worst Volcanic Disaster of the 20th century, Oxford, 2002.

Shepherd, J. B., Tomblin, J. F., and Woo, D. A.: Volcano-seismic crisis in Montserrat, West Indies, 1966-67, B. Volcanol., 35, 143-162, 1971

Tanguy, J.-C.: The 1902-1905 eruptions of Montagne Pelee, Martinique: anatomy and retrospection, J. Volcanol. Geoth. Res., 60, 87-107, 1994.

Tappin, D. R., Watts, P., McMurtry, G. M., Lafoy, Y., and Matsumoto, T.: The Sissano, Papua New Guinea tsunami of July 1998 - offshore evidence on the source mechanism, Mar. Geol., 175, 1-23, 2001.

Tinti, S., Manucci, A., Pagnoni, G., Armigliato, A., and Zaniboni, F.: The 30 December 2002 landslide-induced tsunamis in Stromboli: sequence of the events reconstructed from the eyewitness accounts, Nat. Hazards Earth Syst. Sci., 5, 763-775, doi:10.5194/nhess-5-763-2005, 2005.

Trofimovs, J., Amy, L., Boudon, G., Deplus, C., Doyle, E., Fournier, N., Hart, M. B., Komorowski, J. C., Le Friant, A., Lock, E. J., Pudsey, C., Ryan, G., Sparks, R. S. J., and Talling, P. J.: Submarine pyroclastic deposits formed at the Soufriere Hills Volcano, Montserrat (1995-2003); what happens when pyroclastic flows enter the ocean?, Geology (Boulder), 34, 549$552,2006$.
Van Boskirk, E. J., Voight, B., Watts, P., Widiwijayanti, C., Mattioli, G. S., Elsworth, D., Hidayat, D., Linde, A., Malin, P., Neuberg, J., Sacks, S., Shalev, E., Sparks, R. J., and Young, S. R.: Pyroclastic Flow Generated Tsunami Waves Detected by CALIPSO Borehole Strainmeters at Soufriere Hills, Montserrat During Massive Dome Collapse: Numerical Simulations and Observations, in: AGU Fall Meeting, 2004.

Walder, J. S., Watts, P., Sorensen, O. E., and Janssen, K.: Tsunamis generated by subaerial mass flows, J. Geophys. Res., 108(B5), 2236, doi:10.1029/2001JB000707, 2003.

Ward, S. N. and Day, S.: Ritter Island Volcano - lateral collapse and the tsunami of 1888, Geophys. J. Int., 154, 891-902, 2003.

Watts, P. and Grilli, S. T.: Underwater Landslide Shape, Motion, Deformation, and Tsunami Generation, in: Proceedings of The Thirteenth (2003) International Offshore and Polar Engineering Conference, Honolulu, Hawaii, USA, 2003.

Watts, P. and Waythomas, C. F.: Theoretical analysis of tsunami generation by pyroclastic flows, J. Geophys. Res., 108(B12), 2563, doi:10.1029/2002JB002265, 2003.

Watts, P., Grilli, S. T., Kirby, J. T., Fryer, G. J., and Tappin, D. R.: Landslide tsunami case studies using a Boussinesq model and a fully nonlinear tsunami generation model, Nat. Hazards Earth Syst. Sci., 3, 391-402, doi:10.5194/nhess-3-391-2003, 2003.

Waythomas, C. F., Watts, P., and Walder, J. S.: Numerical simulation of tsunami generation by cold volcanic mass flows at Augustine Volcano, Alaska, Nat. Hazards Earth Syst. Sci., 6, 671-685, doi:10.5194/nhess-6-671-2006, 2006.

Wei, G., Kirby, J., Grilli, S., and Subramanya, R.: A fully nonlinear Boussinesq model for surface waves. I. Highly nonlinear, unsteady waves, J. Fluid Mech., 294, 71-92, 1995.

Zahibo, N.: Tsunami Newsletter, May-June, Tech. rep., International Tsunami Information Center, 2006. 